\title{
Bioactive Platelet Aggregates: Prp, Prgf, Prf, Cgf And Sticky Bone
}

\author{
Viram Upadhayaya ${ }^{\mathrm{a}}$, Aman Arora $^{\mathrm{b}}$, Aditi Goyal ${ }^{\mathrm{c}}$ \\ $A-M D S$, Reader, B-MDS, Professor And Head, C-MDS, PG Student \\ Department Of Prosthodontics, Room,DAV@ Dental College,Model Town,Yamunanagar,Haryana
}

\begin{abstract}
The development of bioactive surgical additives to regulate the inflammation and increase the speed of healing rocess is one of the great challenges in clinical research. Platelets are known to release several growth factors which stimulate tissue regeneration. Several techniques of platelet concentrates have been introduced in surgical field for the prevention of hemorrhage and acceleration of tissue regeneration. This review article focuses on the development of various platelet concentrates, their fabrication procedure, advantages and disadvantages for use in regenerative surgery and healing process.
\end{abstract}

Keywords: Platelet concentrates, Growth factors, Tissue regeneration, Regenerative surgery.

\section{Introduction}

The main goal of the modern surgery is to get a higher rate of clinical healing with least invasiveness procedures. In the last years, the concept of regenerative surgery has been introduced ${ }^{[1]}$ Regeneration is the reconstitution of both hard and soft tissues in structure and function. Regeneration requires an orchestrated sequence of biologic events, such as cell migration, adherence, growth and differentiation to have a potential to increase the success and predictability of regenerative procedures. ${ }^{[2]}$ Platelets play a crucial role in hemostasis and wound healing as they are rich source of growth factors. ${ }^{[3]}$ Growth factors are proteins which regulate in the complex processes of wound healing. They play a main role on cell migration, cell proliferation and angiogenesis in tissue regeneration phase. These growth factors are mainly located in blood plasma and platelets. So, platelet aggregates have been widely used to accelerate tissue regeneration and repair in dental and medical fields. ${ }^{[4]}$

\section{Growth factors in healing process:}

During wound healing, platelets are among the first cells to respond at a wound site, being critical to the initiation of this process. Besides their procoagulant effects, platelets form a rich source of important growth factors. ${ }^{[5]}$ Platelets essentially contain two types of granules - the alpha granules and the dense bodies. The alpha granules contain fibrinogen, fibronectin, factor $\mathrm{V}$ and von wollebrand's factor, platelet derived growth factor (PGDF), transforming growth factor-B (TGF-b), fibroblast growth factor, insulin like growth factor (IGFI and IGF-II), vascular endothelial growth factor (VEGF). The dense bodies contain ADP, ATP, ionised calcium histamine, serotonin and adrenaline. ${ }^{[6]}$

Signalling molecules of importance during bone healing can be categorized into three groups: (i) the pro-inflammatory cytokines (interleukin-1, interleukin-6 and tumor necrosis factor-a), (ii) the transforming growth factor-b superfamily (bone morphogenetic proteins and transforming growth factor-b) and other growth factors (platelet-derived growth factor, fibroblast growth factor and insulinlike growth factors I and II) and (iii) the angiogenic factors [vascular endothelial growth factor, angiopoietins 1 and 2 and matrix metalloproteinases (that degrade bone and cartilage and enable vessel invasion)]. ${ }^{[7]}$ The production and the action of these signaling molecules are summarized in table 1.

Table 1: The production and the action of signaling molecules

\begin{tabular}{|c|c|c|}
\hline Factors & Produced by & Action \\
\hline Cytokines & $\begin{array}{l}\text { Macrophages and } \\
\text { Mesenchymal cells }\end{array}$ & $\begin{array}{l}\text { Exert chemotactic activity on } \\
\text { inflammatory cells, enhance cellular } \\
\text { matrix synthesis and stimulate } \\
\text { angiogenesis. }{ }^{[7,8]}\end{array}$ \\
\hline $\begin{array}{l}\text { Transforming growth } \\
\text { factor-b }\end{array}$ & Osteoblasts & $\begin{array}{l}\text { Stimulates the expression of bone } \\
\text { matrix proteins }{ }^{[9]} \text { and suppresses the } \\
\text { degrading activity of matrix } \\
\text { metalloproteinases and other } \\
\text { enzymes. }{ }^{[10]} \\
\text { Also induces the differentiation or } \\
\text { proliferation of osteoblastic cells while } \\
\text { inhibiting the formation of osteoclast } \\
\text { precursors and, in greater }\end{array}$ \\
\hline
\end{tabular}




\begin{tabular}{|c|c|c|}
\hline & & $\begin{array}{l}\text { concentrations, may exert an } \\
\text { inhibitory effect on mature } \\
\text { osteoclasts. }^{[11]}\end{array}$ \\
\hline $\begin{array}{l}\text { Platelet-derived growth } \\
\text { factor }\end{array}$ & $\begin{array}{l}\text { Platelets, monocytes, } \\
\text { macrophages, endothelial } \\
\text { cells and osteoblasts. }^{[12]}\end{array}$ & $\begin{array}{l}\text { Potent mitogen for mesenchymal cells, } \\
\text { powerful chemotactic agent for } \\
\text { inflammatory cells and a stimulus for } \\
\text { osteoblasts and macrophages. }^{[13]}\end{array}$ \\
\hline Fibroblast growth factor & $\begin{array}{lr}\text { Monocytes, macrophages, } \\
\text { mesenchymal rells, } \\
\text { chondrocytes } \\
\text { osteoblasts }\end{array}$ & Chondrogenesis and bone resorption. \\
\hline $\begin{array}{l}\text { Insulin-like growth } \\
\text { factor }\end{array}$ & $\begin{array}{l}\text { Bone matrix, endothelial } \\
\text { cells, osteoblasts and } \\
\text { chondrocytes. }{ }^{[13,14]}\end{array}$ & $\begin{array}{l}\text { Bone matrix formation and in the later } \\
\text { stages of endochondral bone } \\
\text { formation. }\end{array}$ \\
\hline $\begin{array}{l}\text { Matrix } \\
\text { metalloproteinases }\end{array}$ & $\begin{array}{lr}\text { Macrophages, } & \text { smooth } \\
\text { muscle cells } & \text { and } \\
\text { osteoblasts } & \end{array}$ & $\begin{array}{l}\text { Degrade cartilage and bone. This } \\
\text { allows angiogenic factors to regulate } \\
\text { vessel ingrowth by either the vascular } \\
\text { endothelial growth factor-dependent } \\
\text { pathway or the angiopoietin-dependent } \\
\text { pathway. }{ }^{[15]}\end{array}$ \\
\hline $\begin{array}{l}\text { Vascular endothelial } \\
\text { growth factor }\end{array}$ & 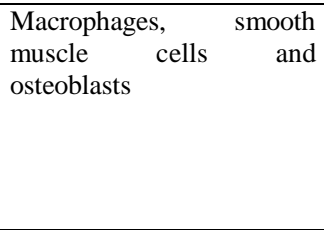 & $\begin{array}{l}\text { Induces the migration and proliferation } \\
\text { of endothelial cells by the use of } \\
\text { transmembrane adhesion proteins } \\
\text { (intergrins) }{ }^{[16]} \text {, also induces relaxation } \\
\text { in the cell-to-cell contact of } \\
\text { endothelial cells, resulting in } \\
\text { hyperpermeability of blood vessels. }\end{array}$ \\
\hline
\end{tabular}

Platelet rich plasma (prp) and platelet rich in growth factor (prgf):

These are first generation platelet concentrates.

Prp - PRP was introduced by Marx. ${ }^{[17]}$

Platelet-rich plasma (PRP) is defined as a high concentration of autologous platelets in a small volume of autologous plasma. ${ }^{[18,19]}$ Specifically, PRP is a platelet concentration with at least $1,000,000 / 1 \mathrm{~L}$ in a $5 \mathrm{~mL}$ volume of plasma, when normal human platelet counts in the blood range from $150,000 / 1 \mathrm{~L}$ to $350,000 / 1 \mathrm{~L}$. The platelets contained in this concentrate of autologous plasma release their alpha granules after the coagulation process has been locally trigged in the wound site. Recently, PRP has become a valuable adjunct to promote healing in many procedures in dental and oral surgery. They include: ablative surgical procedures, mandibular reconstruction and surgical repair of the alveolar cleft, treatment of infrabony periodontal defects and periodontal plastic surgery, as well as procedures relating to the placement of osseointegrated implants. In such procedures, the adhesive nature of PRP facilitates the easier handling of graft material, with more predictable flap adaptation and hemostasis, and a more predictable seal than is the case with primary closure alone. ${ }^{[2-27]}$

Preparation: To concentrate platelets from autologous blood, a double centrifugation technique is required. The first spin (called the hard spin) separates the red blood cells from the plasma that contains the platelets, the white blood cells, and the clotting factors. The second spin (called the soft spin) delicately separates the platelets and white blood cells together with a few red blood cells from the plasma. This soft spin produces the PRP and separates it from the platelet-poor plasma (PPP) free from the interference associated with large numbers of red blood cells. ${ }^{[18]}$

Mode of action: Activating platelets through the clot for- mation initiates the secretion of their growth factors. Within 10 minutes, they secrete $70 \%$ of their stored growth factors and close to $100 \%$ within the first hour. ${ }^{[28]}$ However, complete release of growth factors takes about a week. PRP enhances osteogenesis by inducing and stimulating cells such as osteoblasts, whether derived from the local defect site or from autologous graft tissue. These cells are essential for PRP to enhance bony wound healing. PRP on its own is likely to only be osteoconductive at very best. This highlights the importance of mixing PRP with autogenous bone rather than bone substitutes. ${ }^{[28]}$ Furthermore, PRP in its gel form also pro- vides a scaffold for incoming cells and growth factors, allowing the local physiological mechanism to take over but in an accelerated fashion.

Disadvantages: The first disadvantage of PRP is the variable preparation quality of the techniquesensitive preparation method. The second disadvantage is the time-consuming nature of the PRP preparation method, which usually requires at least $30 \mathrm{~min}$. These disadvantages may be stressful for some clinicians. The third disadvantage is the continued use of bovine thrombin for clotting the liquid preparation of PRP. ${ }^{[29-31]}$

Prgf: To overcome these drawbacks, Anitua developed plasma rich in growth factors (PRGF) by modifying the procedure of PRP preparation. ${ }^{[32]}$ It simplified the preparation protocol and replaced animalderived thrombin with calcium for clotting. 
Preparation: Blood sample is obtained from basilic vein using a large needle to avoid platelet rupture. Sampled blood is combined with anticoagulant and centrifuged. After the centrifugation, PRGF is taken from the bottom of the tube. Calcium Chloride is then added to PRGF. This action promotes the coagulation, usually obtained within at most 10 minutes. At the end of the procedure, we obtain a gelatinous PRGF, to be immediately placed in the surgical site. ${ }^{[33]}$

Disadvantage: It needs a chemical additive as calcium chloride to make gel condition.

\section{Platelet rich fibrin (prf), concentrated growth factor (cgf) and sticky bone:}

These are second generation platelet aggregates.

Prf: It was first developed by Choukroun in france in 2001. PRF consists of an autologous leukocyteplatelet-rich fibrin matrix ${ }^{[34,35]}$, composed of a tetra molecular structure, with cytokines, platelets, cytokines, and stem cells within $\mathrm{it}^{[36,37]}$, which acts as a biodegradable scaffold ${ }^{[38]}$ that favors the development of microvascularization and is able to guide epithelial cell migration to its surface. ${ }^{[37,39]}$ Also, PRF may serve as a vehicle in carrying cells involved in tissue regeneration and seems to have a sustained release of growth factors in a period between 1 and 4 weeks, stimulating the environment for wound healing in a significant amount of time. ${ }^{[40]}$ It has a complex architecture of strong fibrin matrix with favorable mechanical properties and is slowly remodeled, similar to blood clot. ${ }^{[40]}$

Preparation: PRF protocol requires only centrifuged blood without any addition of anticoagulant and bovine thrombin. ${ }^{[34]}$ A blood sample is taken without anticoagulant in 10-mL tubes in a glass or glass-coated plastic tube, then immediately centrifuged at 3,000 rpm for 10 minutes. ${ }^{[34,41,42]}$

The resultant product consists of the following three layers:

- Top-most layer consisting of a cellular plasma.

- PRF clot in the middle.

- Red corpuscle base at the bottom.

After this, it is necessary to put the PRF clot in a sterile cup for approximately 10 minutes to allow the release of the proper serum contained within. Mazor et al ${ }^{[43]}$ reported that clot could be transformed into a membrane through the compression between two sterile gauzes or in a specific tool.

Mode of action: At the beginning, fibrinogen is concentrated in the upper part of the tube before the proper thrombin transforms it into fibrin. ${ }^{[34]}$ Due to the lack of an anticoagulant, blood begins to coagulate as soon as it comes in contact with the glass surface. The contact with a silica surface is required to activate the clot polymerization process. ${ }^{[44]}$ In this sense, PRF may be obtained only in dry glass tubes or glass-coated plastic tubes. Moreover, the silica particles do not represent a risk of cytotoxicity compared with, for example, the bovine thrombin used for PRP preparation. ${ }^{[4]}$ Finally, platelets seem to be trapped massively in the fibrin meshes. In surgical procedures, PRF could serve as a resorbable membrane for guided bone regeneration $(\mathrm{GBR})^{[45]}$, preventing the migration of non-desirable cells into bone defect and providing a space that allows the immigration of osteogenic and angiogenic cells and permits the underlying blood clot to mineralize. ${ }^{[46]}$ However, a normal PRF membrane has rapid degradability (1-2 weeks), but if fibers are cross-linked, it could provide resistance against enzymatic degradation and could be more stable during the healing time. ${ }^{[47]}$

Precaution: For successful preparation of PRF, speedy blood collection and immediate centrifugation before the initiation clotting cascade is absolutely essential. ${ }^{[48]}$ Quick handling is the key to achieve a clinically usable PRF clot.

Advantages: Its preparation is a simplified and efficient technique, with centrifugation in a single step, free and openly accessible for all clinicians. ${ }^{[44,49]}$

- It is obtained by autologous blood sample. ${ }^{[37]}$

- Minimized blood manipulation. ${ }^{[50]}$

- It does not require the addition of external thrombin because polymerization is a completely natural process, without any risk of suffering from an immunological reaction. ${ }^{[34,50]}$

- It has a natural fibrin framework with growth factors within that may keep their activity for a relatively longer period and stimulate tissue regeneration effectively. ${ }^{[40]}$

- It can be used solely or in combination with bone grafts, depending on the purpose. ${ }^{[49,51]}$

- Increases the healing rate of the grafted bone. ${ }^{[50,51]}$

- It is an economical and quick option compared with recombinant growth factors when used in conjunction with bone grafts. ${ }^{[52]}$

- Used as a membrane, it avoids a donor site surgical procedure and results in a reduction in patient discomfort during the early wound-healing period. ${ }^{[53]}$

- The studies of PRF present it to be more efficient and with less controversies on its final clinical results when compared to PRP. ${ }^{[49]}$ 
Cgf: It was introduced by Sacco in 2006. It is essentially an upgraded version of PRF with a strengthened fibrin matrix and boosted growth factors and cytokines. CGF technology has an interesting characteristic ; i.e. the easy and speedy one-step preparation of larger, denser and richer growth factors fibrin matrix than the other solid PRPs. There is a presence of fibrin network constituted by thin and thick fibrillar elements with multiple elements trapped among the fibrin network. CGF seems to possess a good regenerative capacity and versatility. For example, it has been reported that CGF has a positive effect for the following: sinus and alveolar ridge augmentation ${ }^{[54]}$; pre-implant augmentation procedures ${ }^{[55]}$; promotion of in vitro proliferation, osteogenic maturation and mineralization of mesenchymal stem cells and healing of critical-size bone defects in vivo $^{[56]}$; promotion of in vitro periodontal ligament stem cells proliferation ${ }^{[57]}$, management of chronic venous ulcers $^{[58]}$.

\section{Preparation of CGF and Sticky Bone ${ }^{[59]}$ :}

CGF membrane and autologous fibrin glue (AFG) to make sticky bone is prepared at the same time. Before ridge and/or sinus augmentation surgery is performed, 20-60CC of patient's venous blood is taken from patients' vein in patient's forearm, and the blood is divided to one to two non-coated vacutainers to obtain autologous fibrin glue (AFG), which will make sticky bone and two to seven glass coated test tubes without anticoagulants to obtain CGF layer. The blood in the test tubes is centrifuged at 2400-2700 rpm using specific centrifuge (Medifuge, Sil-fradent srl, Sofia, Italy or any other compatible devices) with a rotor turning at alternated and controlled speed for 12 minutes. The centrifugation time for AFG varies from 2-12 minutes. To get higher growth factors, the centrifuge is stopped after 2 minute-centrifugation and take AFG tube out of the centrifuge first. The non-coated tube shows 2 different layers. The upper layer is autologous fibrin glue (AFG) layer and red blood cell is collected in bottom layer which will be is discarded. The vacant slot is filled with water filled test tube for weight balance and continued centrifugation to prepare CGF. After centrifugation, silica coated tube shows three different layers.

The most upper layer is platelet poor plasma, and the middle layer is fibrin buffy coat layer represented by a very large and dense polymerised fibrin block containing the concentrated growth factors. The bottom layer is red blood cell layer. CGF is taken in test tube and placed in the metal storage box and compress with metal cover to convert to CGF membrane. The upper AFG is obtained with syringe and mixed with particulate bone powder and allows for 5-10 minutes for polymerization in order to produce sticky bone which is yellow colored. For acceleration of polymerization of AFG, exudate taken in the bottom of metal storage box after compression of CGF layer is added when AFG and particulate bone graft is mixed. The exudate contains growth factors and autologous thrombin in RBC layer, therefore auto-polymerization will be completed very rapidly. The sticky bone mixed with autologous thrombin in RBC layer shows red in color. This sticky bone doesn't migrate even shaking it thanks to strongly inter-linked fibrin network, so the bone loss on the defect during healing period is minimized without use of bone tack or titanium mesh.

Advantages of CGF: It shows better regenerative capacity and higher versatility. The resulting fibrin clot/block is of a higher quality due to the concentration of fibrinogen, factor XIII and thrombin that is obtained. Factor XIIIa, which is activated by thrombin, cross links the fibrin clot to increase stability, strength and protection against plasmin mediated degradation. Clinically, this translates to a clot with higher tensile strength ( $1.5 \mathrm{~kg}$ after 1 hour vs $500 \mathrm{gm}$ ), adhesive strength, and decrease in haemostatic time (105 secs vs 360 secs). Besides the tensile fibrin mem- brane, a red phase of concentrated red blood cells and platelets is also obtained. This is often mixed with either autogenous or other fillers for a more easy to handle and voluminous cavity filling method. ${ }^{[60]}$

Advantages of Sticky Bone: It is moldable, so well adapted over various shapes of bony defect. Micro and macro movement of grafted bone is prevented, so the volume of bone augmentation is maintained during healing period, therefore the need for block bone and titanium mesh is minimized. Fibrin network entraps platelets and leukocytes to release growth factors, so bone regeneration and soft tissue regeneration is accelerated. No biochemical additives are needed to make sticky bone. Fibrin interconnection also minimizes soft tissue ingrowth into sticky bone graft. ${ }^{[59]}$

Comparison of amount of growth factors among different platelet concentrates ${ }^{[61]}$ :

\begin{tabular}{|l|l|l|l|l|}
\hline $\begin{array}{l}\text { Growth } \\
\text { Factors }\end{array}$ & PGF & PRF & PRP & \\
\hline TGF-b1 & Highest & Highest & $\begin{array}{l}\text { Less than CGF and } \\
\text { PRF Least }\end{array}$ & PRGF \\
\hline PGDF-BB & Highest & Highest & $\begin{array}{l}\text { Less than CGF and Least } \\
\text { PRF }\end{array}$ & $\begin{array}{l}\text { Less than CGF and Least } \\
\text { PRF }\end{array}$ \\
\hline VEGF & Highest & Highest & Lates & \\
\hline
\end{tabular}


Note:

Amount of growth factors and angiogenic potency: CGF/PRF> PRP/PRGF

Potency for proliferation of cells: PRP/PRGF> CGF/PRF

\section{Applications}

These platelet aggregates have applications in many fields:

1. Oral and maxillofacial surgery - Includes ablative surgical procedures, mandibular reconstruction, surgical repair of alveolar cleft, treatment of infrabony periodontal defects and periodontal plastic surgery, as well as procedures related to the placement of osseointegrated implants.

2. Bone reconstruction

3. Tissue engineering

4. Cosmetic and dental implant surgery

5. Sports medicine

6. Dermatology

\section{Discussion}

Growth factors play a major role to repair or generate damaged tissue. Platelets are known to release high quantities of growth factors. ${ }^{[62]}$ Several techniques to collect platelet aggregate have been utilized to accelerate tissue healing in dental and medical field. ${ }^{[63-66]}$ PRP as platelet aggregates was first introduced by Marx et al. PRP has widely been used in the dental field such as sinus augmentation, ridge augmentation, periodontal regeneration and soft tissue healing. PRP and PRGF extract platelet concentrates use pipetting after centrifugation of venous blood in the dental office. The procedure has the possibility of technical error to extract proper platelet concentrates. They use only $10 \%$ of acquired blood. PRF and CGF overcome these disadvantages of PRP and PRGF. Unlike PRP and PRGF; PRF and CGF do not require any chemical and biochemical additives such as bovine thrombin and calcium chloride, to make gel condition. So they are free from risk of cross contamination. ${ }^{[67]}$ They use $30-40 \%$ of the patient's blood. CGF is known to have higher tensile strength, higher growth factors and higher viscosity than PRF, so compressed CGF can be used as barrier membrane with growth factors as an alternative to collagen membrane. This barrier induces faster bone formation and soft tissue healing. Atrophic alveolar ridge is a challenging site to place implant. Guided bone regeneration (GBR) using bone graft and barrier membrane is well established technique for augmentation of alveolar ridges. ${ }^{[68-70]}$ For successful GBR; stability of bone graft, space maintenance, angiogenesis and tension free primary suture are essential. $^{[70,71]}$ Space maintenance with particulate bone graft should be provided during healing period. However, particulate bone graft is easily migrated when grafted on the large horizontal/vertical bone defect. To reconstruct large one or two wall bony defect or for the three dimensional ridge augmentation, bone tack or collagen membrane or titanium mesh is required to contain particulate bone graft during healing but these procedures are surgically time consuming and technique sensitive. As an alternative to titanium mesh or block bone procedure, sticky bone was introduced in 2010. It is basically a solidified bone graft which is entrapped in fibrin network. It does not scatter even upon being shaken with cotton pliers because particulate bone powders are strongly interconnected with each other by fibrin network.

These platelet concentrates has shown promising results and have been developed with an idea to combine the fibrin sealant properties with the growth factors in platelets thereby providing an ideal base for wound healing and regeneration of tissues.

\section{Conclusion}

PRF, CGF and sticky bone are easy to make and they are very effective materials for reconstruction of edentulous alveolar bone defect. CGF is effective to regenerate bone formation associated with GBR and GTR procedure. CGF preparations would not only function as scaffolding material but also as a reservoir to deliver certain growth factors at the site of application. Second generation platelet concentrates are more potently capable of inducing angiogenesis and subsequent wound healing/ tissue regeneration than first generation platelet concentrates.

\section{References}

[1]. Giannini S, Cielo A, Bonanome L, Rastelli C, Derla C, Corpaci F, Falisi G. Comparison between PRP, PRGF, and PRF: lights and shadows in three similar but different protocols. Eur Rew Med Pharmacol Sci. 2015; 19: 927-930.

[2]. Kumar AP, Reddy GV, Babu PR, Reddy GJ. Platelet rich fibrin - A second regeneration platelet concentrate and advances in PRF. Indian J Dent Adv. 2015; 7(4): 251-254.

[3]. Gassling VL, Açil Y, Springer IN, Hubert N, Wiltfang J. Platelet-rich plasma and platelet-rich fibrin in human culture. Oral Surg, Oral Med, Oral Pathol, Oral Radiol Endod. 2009; 108(1): 48-55

[4]. Clark RA. Fibrin and wound healing. Ann N Y Acad Sci. 2001; 936: 355-67.

[5]. Nikolidakis D, Jansen JA. The biology of platelet-rich plasma and its application in oral surgery: literature review. Tissue Engineering: Part B. 2008; 14: 249-258. 
[6]. Mansour P; Kim P. Use of concentrated growth factor (CGF) in implantology. Australasian Dental Practice. 2010(Mar/Apr); p162.

[7]. Dimitriou R, Tsiridis E, Giannoudis PV. Current concepts of molecular aspects of bone healing. Injury 2005; 36: 1392-1404.

[8]. Kon T, Cho TJ,Aizawa T, Yamazaki M, Nooh N, Graves D, Gerstenfeld LC, Einhorn TA. Expression of osteoprotegrin, receptor activator of NK-kappaB ligand (Osteoprotegrin ligand) and related proinflammatory cytokines during fracture healing. J Bone Miner Res. 2001; 16: 1004-1014

[9]. Wrana JL, Maeno M, Hawrylyshyn B, Yao KL, Domenicucci C, Sodek J. Differential effects of transforming growth factor - beta on synthesis of extracellular matrix proteins by normal fetal rat calvarial bone cell population. J Bell Biol. 1988; 106: 915-924

[10]. Overall CM, Wrana JL, Sodek J. Independent regulation of collagenase, 72-kDa progelatinase and metalloendoproteinase inhibitor expression in human fibroblasts by transforming growth factor-beta. J Biol Chem. 1989; 264: 1860-1869.

[11]. Bonewald LF, Mundy GR. Role of transforming growth factor-beta in bone remodeling. Clin Orthop Relat Res.1990; 60: 261-276

[12]. Andrew JG, Hoyland JA, Freemont AJ, Marsh DR. Platelet derived growth factor expression in normally healing human fractures. Bone 1995; 16: 455-460

[13]. Lieberman JR, Daluiski A, Einhorn TA. The role of growth factors in repair of bone. Biology and clinical applications. J Bone Joint Surg Am. 2002; 84-A: 1032-1044

[14]. Solhiem E, Growth factors in bone. Int Orthop. 1998; 22: 410-416.

[15]. Gerstenfeld LC, Cullinane DM, Barnes GL, Graves DT, Einhorn TA. Fracture healing as the postnatal developmental process: molecular, spatial, and temporal aspects of its regulation. J Cell Biochem. 2003; 88: 873-884.

[16]. Lakey I, Akella R, Ranieri J: Angiogenesis: implications for tissue repair. Bone Engeneering, Toronto, Canada: em squred incorporated. 2000; 137-141.

[17]. Marx RE, Carlson ER, Eichstaedt RM, Schimmele SR, Strauss JE, Georgeff KR. Platelet rich plasma: Growth factor enhancement for bone grafts. Oral Surg Oral Med Oral Pathol Oral Radiol Endod. 1998 Jun; 85(6): 638-46.

[18]. Marx RE. Platelet rich plasma (PRP): what is PRP and what is not PRP? Implant Dent. 2001; 10: 225-228

[19]. Marx RE. Platelet rich plasma: A souce of multiple autologous growth factors for bone grafts. In Tissue Engineering: Applications in Maxillofacial Surgery and Periodontics. Quintessence 1997; 71-82.

[20]. Fennis JP, Stoelinga PJ, Jansen JA. Mandibular reconstruction : a histological and histomorphometric study on the use of autogenous scaffolds, particulate corticancellous bone grafts and platelet rich plasma in goats. Int J Oral Maxillofac Surg. 2004; 33 : 48-55.

[21]. Corso DM, Vervelle A, Simonpieri A, Jimbo R, Inchingolo F, Sammartino G, Dohan Ehrenfest DM. Current knowledge and perspectives for the use of platelet rich plasma (PRP) and platelet rich fibrin (PRF) in oral and maxillofacial surgery part 1: Periodontal and dentoalveolar surgery. Curr Pharm Biotechnol. 2012; 13: 207-230.

[22]. Plachokova AS, Nikolidakis D, Mulder J, Jansen JA, Cruegers NH. Effect of platelet rich plasma on bone regeneration in dentistry: a systematic review. Clin Oral Implant Res. 2008; 19: 539-545.

[23]. Bae JH, Kim YK, Myung SK. Effects of platelet rich plasma on sinus bone graft: meta-analysis. J Periodontal. 2011; 82: 660-667.

[24]. Holly D, Mracna J. The use of platelet rich plasma with guided tissue regeneration indefects caused by periodontal diseases. Bratisl Lek Listy. 2009; 110: 669-671

[25]. Choi BH, Im CJ, Huh JY, Suh JJ, Lee SH. Effect of platelet rich plasma in bone regeneration in autogenous bone graft. Int J Oral Maxillofac Surg. 2004; 33: 56-59.

[26]. Arora NS, Ramanayake T, Ren YF, Romanos GE. Platelet rich plasma in sinus augmentation procedures: a systematic literature review: Part II. Implant Dent. 2010; 19: 145-157.

[27]. Nikolidakis D, Wolke JG, Jansen JA: Effect of platelet rich plasma on the early bone formation around Ca-P-coated and non-coated oral implants in cortical bone. Clin Oral Implants Rec. 2008; 19: 207-13.

[28]. Marx, R.E., Platelet rich plasma (PRP): Evidence to support its use. Journal of oral and maxillofacial surgery: Official Journal of American Association of Oral and Maxillofacial Surgeons. 2004; 629(4): 489-496.

[29]. Alsousou J, Thompson M, Hulley P.,Noble P., Willet K. The biology of platelet rich plasma and its application in trauma and orthopaedic surgery: a review of literature. J Bone Joint Surg Br. 20090; 91: 987-96.

[30]. Davis VL, Abukabda AB, Radio NM, Witt-Enderby PA, Clafshenkel WP, Cairone JV, Rutkowski JL. Platelet rich preparations to improve healing. Part II: platelet activation and enrichment leukocyte inclusion, and other selection criteria. J Oral implan tol. 2014; 40: 511-21.

[31]. Lee KS, Wilson JJ, Rabago DP, Baer GS, Jacobson JA, Borrero CG. Musculoskeletal applications of platelet rich plasma: fad or future? Am J Roentgenol. 2011; 196: 628-36.

[32]. Anitua E. The use of Plasma Rich Growth Factors(PRGF) in oral surgery. Pract Proced Aesthet Dent. 2001; 13: 487-93.

[33]. Anitua E, Sanchez M, Orive G, Andia I. The potential impact of the preparation rich in growth factors (PRGF) in different medical fields. Biomaterials 2007; 28: 4551-4560.

[34]. Dohan DM, Choukroun J, Diss A, Dohan SL, Dohan AJ, Mouhyi J and Gogly B. Platelet-rich fibrin (PRF): a second-generation platelet concentrate.Part-1 :technological concepts and evolution. Oral surg Oral med Oral Pathol Oral Radiol Endod. 2006; 101: e37-44.

[35]. Gupta V, Bains Bk, Singh GP,Mathur A and Bains R. Regenerative potential of platelet rich fibrin in dentistry: literature review. Asian J Oral Health Allied Sci. 2011; 1: 22-28.

[36]. Dohan DM, Choukroun J, Diss A, Dohan SL, Dohan AJ,Mouhyi J and Gogly B. Platelet rich Fibrin (PRF): second generation platelet concentrate. Part II: platelet related biologic features. Oral surg Oral Med Oral Pathol Oral Radiol Endod. 2006; 101: e4550 .

[37]. Choukroun J, Diss A, Simonpieri A, Girard MO, Schoeffler C, Dohan SL, Dohan AJ, Mouhyi J and Dohan DM. Platelet rich fibrin(PRF): a second generation platelet concentrate. Part IV: clinical effects on tissue healing.Oral Surg Oral Med Oral Pathol Oral Radiol Endod. 2006; 101: e56-60.

[38]. Li Q, Pan S, Dangaria SJ, Gopinathan G, Kolokythas A, Chu S, Geng Y, Zhou Y and Luan X.Platelet -rich fibrin promotes periodontal regeneration and enhances alveolar bone augmentation. Biomed Res Int. 2013; 2013: 638043.

[39]. Dohan DM, Choukroun J, Diss A, Dohan SL, Dohan AJ, Mouhyi J, Gogly B. Platelet rich fibrin : a second generation platelet concentrate. Part III: Leucocyte activation: a new feature for platelet concentrates? Oral Surg Oral Med Oral Pathol oral Radiol Endod. 2006; 101: e51-55.

[40]. Wu CL, Lee SS, Tsai CH, Zhao JH and Chang YC. Platelet rich fibrin increases cell attachment, proliferation and collagen related protein expression of human osteoblasts. Aust Dent J. 2012; 57: 207-212.

[41]. Gassling VL, Acil Y, Springer IN, Hubert N and Wiltfang J. Platelet rich plasma and platelet rich fibrin in human cell culture. Oral Surg Oral Med Oral Pathol Oral Radiol Endod. 2009; 108: 48-55. 
[42]. Huang FM, Yang SF, Zhao JH and Chang YC. Platelet rich fibrin increases proliferation and differentiation of human dental pulp cells, J Endod. 2010; 36: 1628-1632

[43]. Mazor Z, Horowitz RA, Del Corso M, Prasad HS, Rohrer MD and Dohan Ehrenfest DM. Sinus augmentation with simultaneous implant placement using Choukroun's platelet rich fibrin as the sole grafting material: a radiologic and histologic study at 6 months. J periodontal. 2009; 80: 2056-2064.

[44]. Dohan DM, Del Corso M, Charrier J-B. Cytotoxicity analyses of Choukroun's platelet rich fibrin (PRF) on a wide range of human cells: The answer to a commercial controversy. Oral Surg Oral Med Oral Pathol oral Radiol Endod. 2007; 103: 587-593

[45]. Chang YC and Zhao JH. Effects of platel rich fibrin on human periodontal ligament fibroblasts and application of periodontal infrabony defects. Aust Dent J. 2011; 56: 365-371.

[46]. Molly L, Quirynen M, Michiels K and Van Steenberghe D. Comparison between jaw bone augmentation by means of a stiff occlusive titanium membrane or an autologous hip graft: a retrospective clinical assessment. Clin Oral Implants Res. 2006; 17: 481487 .

[47]. Kawase T, Kamiya M, Kobayashi M, Tanaka T, Okuda k, Wolff LF and Yoshie H. The heat compression technique for the conversion of platelet rich fibrin preparation to a barrier membrane with reduced rate of biodegradation. $\mathrm{J}$ Biomed Mater Res $\mathrm{B}$ Appl Biomatar. 2015; 103: 825-31.

[48]. Anilkumar K, Geetha A, Umasudhakar, Ramakrishnan T, Vijayalakshmi R, Pameela E. Platelet-rich-fibrin: A novel root coverage approach. J Indian Soc Periodontol. 2009; 13: 50-4

[49]. Simonpieri A, Del Corso M, Vervelle A, Jimbo R, Inchingolo F, Sammartino G and Dohan Ehrenfest DM. Current Knowledge and perspectives for the use of Platelet Rich Plasma (PRP) and Platelet Rich fibrin (PRF) in oral and maxillofacial surgery part 2:Bone Graft , implant and reconstructive surgery. Curr Pharm Biotechnol. 2012; 13: 1231-1256.

[50]. Kang YH, Jeon SH, Park JY, Chung JH, Choung YH, Choung HW, Kim ES, Choung PH. Platelet-rich fibrin is a Bioscaffold and reservoir of growth factors for tissue regeneration. Tissue Eng Part A. 2011; 17: 349-359.

[51]. Choukroun J, Diss A, Simonpieri A, Girard MO, Schoeffler C, Dohan SL, Dohan AJ, Mouhyi J, Dohan DM. Platelet-rich fibrin (PRF): a second-generation platelet concentrate. Part V: histologic evaluations of PRF effects on bone allograft maturation in sinus lift. Oral Surg Oral Med Oral Pathol Oral Radiol Endod. 2006; 101: 299-303.

[52]. Rao SG, Bhat P, Nagesh KS, Rao GH, Mirle B, Kharbhari L, Gangaprasad B. Bone regeneration in extraction sockets with autologous platelet rich fibrin gel. J Maxillofac Oral Surg. 2013; 12: 11-16.

[53]. Jankovic S, Aleksic Z, Klokkevold P, Lekovic V, Dimitrijevic B, Kenney EB, Camargo P. Use of platelet-rich fibrin membrane following treatment of gingival recession: a randomized clinical trial. Int J Periodontics Restorative Dent. 2012; 32: e41-50.

[54]. Sohn DS, Heo JU, Kwak DH, Kim DE, Kim JM, Moon JW, Lee JH, Park IS. Bone regeneration in maxillary sinus using autologous fibrin rich block with concentrated growth factors alone. Implat Dent. 2011; 20(5): 389-395.

[55]. Tadi A, Puskar T, Petronijevi B. Application of fibrin rich blocks with concentrated growth factors in pre- implant augmentation procedures. Med Pregl. 2014; 67: 177-180

[56]. Honda H, Tamai N, Naka N, Yoshikawa H, Myoui A. Bone tissue engineering with bone marrow derived stromal cells integrated with concentrated growth factor in Rattus norvegicus calvaria defect model. J Artif Organs. 2013; 16: 305-315.

[57]. Yu B, Wang Z. Effect of concentrated growth factors on beagle periodontal ligament stem cells in vitro . Mol Med Rep. 2014; 9: $235-242$

[58]. Romano F, Paolino FM, Rizzo BA, Russo A, Southworth S, Serra R, Gallelli L. The use of growth factors, CD34+ cells and fibrin for the management of chronic venous ulcers. Int Wound J. 2016 Oct;13(5):1011-3.

[59]. Kim J. Utilization of autologous concentrated growth factors (CGF) enriched bone graft matrix (sticky bone) and CGF-Enriched fibrin membrane in implant dentistry. 2015 (Dec); 7(10): 11-28.

[60]. Mansour P, Kim P. Use of concentrated growth factors (CGF) in implantology. Silfradent. 2015 (Apr).

[61]. Masuki H, Okudera T, Watanebe T, Suzuki M, Nishiyama K, Okudera H, Nakata K, Uematsu K, Su CY And Kawase T. Growth factor and pro-inflammatory cytokine contents in Platelet Rich Plasma(PRP), Plasma Rich Growth Factors (PRGF), Advanced Platelet Rich Fibrin (A-PRF), and Concentrated Growth Factors (CGF). Int J Implant Dentistry. 2016; 2: 19.

[62]. Intini G. The use of platelet-rich plasma in bone reconstruction therapy. Biomaterials 2009; 30: 4956-4966.

[63]. Marx RE, Carlson ER, Eichstaedt RM, Schimmele SR, Strauss JE, Georgeff KR. Platelet-rich plasma: Growth factor enhancement for bone graft. Oral Surg Oral med Pathol Oral Radiol Endod. 1998; 85(6): 638-646.

[64]. Anitua E, Orive G, Pla R, Roman P, Serrano V, Andia I. The effects of PRGF on bone regeneration and on titanium implant osseointegration in goats: a histologic and histomorphometric study. J Biomed mater Res A. 2009; 91(1): 158-165

[65]. Plachokova AS., Nikolidakis D, Mulder J, Jansen JA, Creugers NH. Effect of platelet rich plasma on bone regeneration in dentistry: a systematic review. Clin Oral Implants Res. 2008; 19(6): 539-545.

[66]. Corigliano M, Sacco L, Baldoni E., CGF-una proposta terapeutica per la medicina rigenerativa. Odontoiatria $\mathrm{n}^{0} 1$-anno XXIXmaggio. 2010; 69-81.

[67]. Ehrenfest DM, Rasmusson L, Albrektsson T. Classification of platelet concentrates: from pure platelet-rich plasma (P-PRP) to leucocyte- and platelet-rich fibrin (L-PRF). Trends Biotechnol. 2009; 27(3): 158-67.

[68]. Dahlin C, Linde A, Gottlow J, Nyman S. Healing of bone defects by guided tissue regeneration. Plast Recontr Surg. 1988; 81(5): 672-676.

[69]. WILSON TG Jr., BUSER D. Advances in the use of guided tissue regeneration for localized ridge augmentation in combination with dental implants. Tex Dent J. 1994;111(7):5, 7-10

[70]. Wang HL, Boyapati L. "PASS" principles for predictable bone regeneration. Implant Dent. 2006; 15(1): 8-17.

[71]. Wang HL, AL-Shammari K. HVC ridge deficiency classification: a therapeutically oriented classification. Int J Periodontics Restorative dent. 2002; 22(4): 335-343. 